\title{
Genetic Aspects of Hepatocellular Carcinogenesis
}

\author{
MEHMET OZTURK, Ph.D
}

\begin{abstract}
Hepatocellular carcinoma (HCC) is linked etiologically to viruses (hepatitis B virus [HBV] and hepatitis $C$ virus $[H C V]$ ), chemical carcinogens (i.e., aflatoxins), and other environmental and host factors causing chronic liver injury. Some hepatoblastomas may be linked to inherited gene mutations, but adult hereditary HCC appears to be rare. HCCs display gross genomic alterations, including DNA rearrangements associated with HBV DNA integration, loss of heterozygosity, and, less importantly, chromosomal amplifications and loss of imprinting. Many genes with somatic mutations have now been identified in these tumors. Most frequently involved genes are tumor suppressor genes such as p53, M6P/IGF2R, $\beta$-catenin, p16INK4A, and retinoblastoma genes. Most identified mutations are somatic, but germline mutations of $\mathrm{p} 16 \mathrm{INK} 4 \mathrm{~A}, \mathrm{APC}$, and BRCA2 have also been reported. Oncogenic activation of several cellular genes such as cyclin $D$ and cyclin $A$ have been described in HCC, but the possible implication of candidate viral oncogenes (i.e., X protein of $H B V$ ) is still debated. A comprehensive analysis of all the genetic changes described for HCC demonstrates that at least four different growth regulatory pathways are altered in these tumors. However, each pathway appears to be implicated in a limited fraction of these tumors, suggesting that HCCs are genetically heterogenous neoplasms. This genetic heterogeneity correlates with the heterogeneity of etiologic factors implicated in $\mathrm{HCC}$.
\end{abstract}

KEY WORDS: hepatocellular carcinoma, primary liver cancer, $p 53, p 16 I N K 4 A$, cyclin $\mathrm{D}, \beta-\mathrm{catenin}, M 6 P / I G F 2 R$

Hepatocellular carcinoma (HCC) cells often display chromosomal changes such as polyploidy, loss of heterozygosity ( $\mathrm{LOH})$, allelic imbalance (AI), amplifications, and translocations. ${ }^{1}$ It has also been known for a long time that hepatitis B virus (HBV) DNA causes chromosomal rearrangements by integration into the host genome. ${ }^{2}$ It is expected that the chromosomal regions that undergo tumor-specific changes harbor critical genes involved directly (oncogenes and tumors suppressor genes) or indirectly (DNA repair genes) in carcinogenesis. To date, a dozen genes, including p53, mannose-6- phosphate/insulin-like factor 2 receptor $(M 6 P / I G F 2 R)$, $\beta$-catenin, retinoblastoma $(R B I), p / 6 I N K 4 A$, adenomatosis polyposis coli $(A P C)$, breast cancer gene 2 (BRCA2), cyclin $\mathrm{A}$, cyclin $\mathrm{D}$, and insulin-like growth factor 2 (IGF2) have been shown to be altered in HCC and/or hepatoblastoma (Table 1). This list will probably grow over the next years to include many more genes. There are at least two reasons to explain the high number of altered genes in HCC. First, solid tumors of the adult may need the accumulation of many genetic alterations before they become clinically detectable. Indeed,

\footnotetext{
Ohjectives

Upon completion of this article, the reader should be able to: 1) list the factors that are etiologically linked to hepatocellular carcinoma; 2) state the most frequently involved genes; and 3) recognize the four different growth regulatory pathways that are altered in these tumors.

Accreditation

The Indiana University School of Medicine is accredited by the Accreditation Council for Continuing Medical Education to sponsor continuing medical education for physicians.

Credit

The Indiana University School of Medicine designates this educational activity for a maximum of 1.0 hours credit toward the AMA Physicians Recognition Award in category one.
}

Disclosure

Statements have been obtained regarding the author's relationships with financial supporters of this activity. There is no apparent conflict of interest related to the context of participation of the author of this article.

From the Department of Molecular Biology and Genetics, Bilkent University, O6533 Ankara, Turkey. Reprint requests: Dr. Mehmet Ozturk, Dept. of Molecular Biology and Genetics, Bilkent University, 06533 Ankara, Turkey.

Copyright (C) 1999 by Thieme Medical Publishers, Inc., 333 Seventh Avenue, New York, NY 10001, USA. Tel.:

$+1(212)$ 760-0888 x 132.0272-8087/1999/1098-8971 (1999) 19:03:0235-0242:SLD00010X 
TABLE 1. Genetic Alterations in Hepatocellular Carcinoma and Hepatoblastoma

\begin{tabular}{|c|c|c|c|}
\hline Gene & Mutation (\%) & Other Alterations & References \\
\hline$p 53$ & 28 & HBx interaction & see Table 2 \\
\hline$M 6 P / I G F 2 R$ & $18-33$ & $\mathrm{HD}$ & $21,36,44$ \\
\hline TGFRB2 & 0 & - & 23 \\
\hline$R B I$ & 15 & LOH, HD & $11, \ddagger 45-50$ \\
\hline$p 15 I N K 4 B$ & 0 & $\mathrm{HD}$ & 50,51 \\
\hline p16INK4A* & $0-55$ & HD, Methylation & $50-54$ \\
\hline$p 21$ & 5 & 一 & 55 \\
\hline Cyclin $\mathrm{D}^{\dagger}$ & $11-13$ & 一 & 56,57 \\
\hline Cyclin $\mathrm{A}^{\dagger}$ & 19 & $\mathrm{HBV}$ integration & 58,59 \\
\hline$\beta$-catenin & $19-26$ & - & 30,31 \\
\hline$A P C^{*}$ & $62^{\ddagger}$ & $\mathrm{LOH}$ & $11,32-35,37$ \\
\hline E-cadherin & NR & LOH, Methylation & 60,61 \\
\hline$B R C A 2^{*}$ & 5 & $\mathrm{LOH}$ & 62 \\
\hline Smad2 & $0-2$ & - & 24,25 \\
\hline Smad4 & $0-6$ & - & 24,25 \\
\hline$h M L H I$ & NR & $\mathrm{LOH}$ & 63 \\
\hline$h M S H 2$ & NR & $\mathrm{LOH}$ & 63 \\
\hline$I G F 2$ & NR & LOI & $38-43$ \\
\hline K-ras & $0-17$ & - & $90-95$ \\
\hline $\mathrm{N}-$ ras & $0-16$ & Amplification & $90,91,93,95,96$ \\
\hline H-ras & $0-10$ & Methylation & $73,91,93,95,97,98$ \\
\hline$c-m y c^{\dagger}$ & $0-50$ & - & 99,100 \\
\hline $\mathrm{N}-m y c^{\ddagger}$ & 0 & - & 99,101 \\
\hline
\end{tabular}

*Somatic and germline mutations.

${ }^{\dagger}$ Amplification.

$\ddagger$ In hepatoblastoma only.

HD, homozygous deletion.

LOH, loss of heterozygosity.

LOI, loss of imprinting.

the well-known "latent period" between the first exposure to an etiologic agent (i.e., infection with HBV) and the development of HCC is in favor of such a hypothesis. ${ }^{3}$ Second, the multiplicity of genetic alterations in HCC may indicate that different etiologic factors affect different sets of target genes in hepatocytes. This etiologically defined genetic heterogeneity of HCC results in a phenotypic heterogeneity of these tumors. In other words, distinct but related growth regulatory pathways are altered during hepatocarcinogenesis. As discussed later, at least four different pathways are altered in human HCCs.

\section{p53 GENE}

Many reports now indicate that the $p 53$ gene, which is located on chromosome $17 \mathrm{p}$, is mutated in about $30 \%$ of HCCs worldwide (for a recent review, see ref. 4). All reported $p 53$ mutations in $\mathrm{HCC}$ are somatic. Therefore, germline mutations of $p 53$ appear not to predispose to HCC. Both the frequency and the type of $p 53$ mutations are different depending on geographic location and suspected etiology of these tumors (Table 2). An HCCspecific codon 249 mutation (AGG $\rightarrow$ AGT) leading to an arginine to serine substitution (R249S), suspected to be induced by aflatoxins, was found in most HCCs from geographic areas with high incidence of $\mathrm{HCC}$ and a high risk of exposure to aflatoxins..$^{5-7}$ This mutation was found in 50\% of HCCs from Mozambique, 8,950 to $75 \%$ of HCCs from Qidong province of China, $6,10,11$ and $67 \%$ of HCCs from Senegal. ${ }^{7}$ A worldwide study by Ozturk et al. ${ }^{8}$ suggested a close correlation between the presence of codon 249 mutations in HCC and high risk of aflatoxin intake. This early study has now been largely confirmed by others. As shown in Table 1, the codon 249 mutation is present in $36 \%$ of tumors from Africa and $32 \%$ of tumors from China, respectively. These two regions of the world are known for high incidence of $\mathrm{HCC}$, where both HBV and aflatoxins are recognized as major etiologic factors. In contrast, the codon 249 mutation is seen in less than $4 \%$ of HCCs from Japan, Europe, and North America, where HBV and hepatitis $\mathrm{C}$ virus ( $\mathrm{HCV})$, but not aflatoxins, are the main etiologic factors. The overall frequency of codon 249 mutations in the world is $11 \%$. Mutations affecting other codons of the $p 53$ gene are detected in $\mathrm{HCC}$, and their worldwide frequency is $18 \%$. The frequency of all $p 53$ mutations in HCC varies between $15 \%$ in Europe and $42 \%$ in China, with a worldwide frequency of $27 \%$ (see Table 2 for a detailed analysis of $p 53$ mutations). Thus, $p 53$ gene is mutated in about a third of HCCs, but only a third of these mutations can be etiologically linked to a high risk of aflatoxin exposure. Therefore, $p 53$ mutations can occur in HCC independent of aflatoxin risk, and in HBV or HCV infection. However, Unsal et al. ${ }^{9}$ reported an 
TABLE 2. Frequency of $p 53$ Mutations in Hepatocellular Carcinoma

\begin{tabular}{llll}
\hline Region & $\mathrm{p} 53-249$ ser & $\mathrm{p} 53$-other & p53-total \\
\hline North America & $4 / 89 *$ & $6 / 34$ & $6 / 34$ \\
& $(4 \%)$ & $(18 \%)$ & $(18 \%)$ \\
South America & $3 / 16$ & $\mathrm{ND}$ & $\mathrm{ND}$ \\
& $(19 \%)$ & - & - \\
Europe & $0 / 131$ & $13 / 109$ & $23 / 151$ \\
& $(0 \%)$ & $(12 \%)$ & $(15 \%)$ \\
Africa & $19 / 53$ & $2 / 26$ & $11 / 26$ \\
& $(36 \%)$ & $(8 \%)$ & $(42 \%)$ \\
Chinas & $62 / 191$ & $16 / 132$ & $50 / 132$ \\
& $(32 \%)$ & $(12 \%)$ & $(38 \%)$ \\
Japan & $7 / 292$ & $53 / 232$ & $94 / 353$ \\
& $(2 \%)$ & $(23 \%)$ & $(27 \%)$ \\
Otherl & $20 / 265$ & $57 / 265$ & $79 / 273$ \\
Total & $(8 \%)$ & $(22 \%)$ & $(29 \%)$ \\
& $115 / 1037$ & $147 / 798$ & $263 / 969$ \\
& $(11 \%)$ & $(18 \%)$ & $(27 \%)$ \\
\hline
\end{tabular}

Data were compiled from references $6,7,9-11,45,64-89,98$ and 102-104. The numbers do not add up for two reasons: in some studies only the p53-249 mutation was reported; in some others only the information of the total number of mutations was reported.

*U.S.A. including Alaska.

${ }^{+}$Mexico only.

${ }^{\ddagger}$ South Africa, Mozambique, and Senegal only.

sMainland China and Hong Kong.

"Australia, Singapore, South Korea, Taiwan, Thailand.

apparent association between the presence of $\mathrm{X}$ gene coding sequences of $\mathrm{HBV}(\mathrm{HBx})$ and wild-type $p 53$ in HCC. Based on this observation, a possible interference of HBV with wild-type $p 53$ function was suggested. ${ }^{9}$ Indeed, recent studies showed that $\mathrm{HBx}$ protein encoded by the $\mathrm{X}$ region of $\mathrm{HBV}$ interacts with wild-type $p 53$ protein both physically and functionally. ${ }^{12-15}$ These observations suggest that the suspected oncogenic activity of $\mathrm{HBx}$ protein is linked to functional inactivation of wild-type $p 53$ protein, as observed with other viral proteins with transforming activity. However, the interaction of $\mathrm{HBx}$ with $p 53$ was shown only experimentally. It is presently unclear whether $\mathrm{HBx}-p 53$ interactions really occur in $\mathrm{HBV}$-infected hepatocytes and/or in HCC cells with integrated HBV DNA sequences.

Frequent involvement of p53 mutations in $\mathrm{HCC}$ is not surprising for several reasons. First, the $p 53$ gene is the only known gene to be mutated at a very high frequency in tumors of different origin. ${ }^{16}$ Second, this protein is involved in different cellular processes (cell cycle arrest, apoptosis, differentiation, angiogenesis, etc.), all critically involved in the development of malignancy. ${ }^{17}$ Under physiologic conditions, p53 protein is complexed with MDM2 protein that promotes a rapid degradation of p53. MDM2-p53 complexes are inhibited either by p19ARF (induced by both cellular and viral oncogenes) or by $\mathrm{N}$-terminal phosphorylation of $p 53$ by DNA-dependent protein kinase. This leads to an accumulation and functional activation of p53 in cells, leading to either cell cycle arrest by $\mathrm{p} 21$ or apoptosis by bax induction. Thus, p53 protein appears to be involved in a growth control response to abnormal oncogene expression and DNA damage. ${ }^{17}$ In patients with chronic liver disease, the risks of oncogene activation and DNA damage are elevated. As stated earlier, HBx may have an oncogenic activity and aflatoxins are potent DNA damaging agents. ${ }^{1,2}$

\section{p16INK4A, CYCLIN D, AND RETINOBLASTOMA GENES}

These three genes encode for proteins involved in the regulation of the $\mathrm{Gl}$ phase of the cell cycle. Cyclin D forms active complexes with CDK4 protein, whereas p16 protein is an inhibitor of CDK4 activity. ${ }^{18}$ The retinoblastoma protein $(\mathrm{pRb})$ is the main known substrate of CDK4. In nonproliferating cells, $\mathrm{pRb}$ protein forms complexes with E2F transcription factors. When complexed to $\mathrm{pRb}$, E2Fs are transcriptionally inactive. Upon phosphorylation by $\mathrm{CDK} 4, \mathrm{pRb}$ is released from its complexes and "free E2Fs" promote the initiation of DNA synthesis. ${ }^{19}$ These observations predict that the loss of $\mathrm{pRb}$ protein or its aberrant phosphorylation will lead to a loss of growth control at the G1 phase of the cell cycle. Increased phosphorylation of $\mathrm{pRb}$ may result from an aberrant activation of CDK4 by either an excess of cyclin D and/or a deficit in pl6 protein. Recent studies demonstrated that all three genes, namely $R B 1$, 
p16INK4A, and cyclin $\mathrm{D}$, undergo structural alterations in $\mathrm{HCC}$. The retinoblastoma gene $(R B I)$ is one of the tumor suppressor genes studied in HCC just after the implication of $p 53$ in these tumors. $\mathrm{LOH}$ at the $R B I$ gene locus is quite frequent in HCC. In addition, RBI mutations were observed in $15 \%$ of these tumors (Table 1).

The pl6INK4A gene, which is located at chromosome $9 \mathrm{p}$, codes for two alternatively spliced transcripts. 17.18 One of the transcripts is for p16 protein, an inhibitor of cyclin-dependent kinases 4 and 6.18 pl6INK4A status in HCC has been studied independently by several laboratories. Both germline and somatic mutations of pl6INKA were found in HCC patients. It was also reported that about $50 \%$ of $\mathrm{HCC}$ display de novo methylation of $p 16 I N K 4 A$, as observed in other cancers (see Table 1 and references therein). It is known that de novo methylation is a mechanism involved in gene silencing. ${ }^{20}$ Therefore, one can assume that $\mathrm{HCC}$ cells with methylated pI6INK4A are unable to express the gene, leading to the loss of a cyclin-dependent kinase inhibitor protein.

As shown in Table 1, cyclin D and cyclin A genes were shown to be amplified in 10-20\% of HCCs. It is noteworthy that $R B 1, p I 6 I N K A$, and cyclin genes are mutated individually in 10 to $20 \%$ of HCCs. Although this frequency is not high, their involvement in the same growth regulatory pathway implies that when combined, these mutations will lead a loss of growth control in more than $30 \%$ of HCCs.

\section{M6P/IGF2 RECEPTOR, SMAD2, AND SMAD4 GENES}

The mannose-6-phosphate/insulin-like growth factor 2 receptor (M6P/IGF2R) is involved in the activation of transforming growth factor beta (TGF- $\beta$ ), whereas $S M A D 2$ and SMAD4 genes are intracellular mediators of TGF- $\beta$, which induces both growth inhibition and apoptotic cell death in hepatocytes. ${ }^{21-23}$ After the demonstration of LOH at the M6P/IGF2R gene locus by De Souza et al.,21 several reports described that the $M G P / I G F 2 R$ gene is mutated in 18 to $33 \%$ of HCCs (Table 1). SMAD2 and SMAD4 genes appear to be mutated in less that $10 \%$ of these cancers. ${ }^{24,25}$ In contrast, no mutation of TGF- $\beta$ receptor type II was found in HCC. ${ }^{24}$ Taken together, these observations demonstrate that at least three genes involved in TGF- $\beta$-mediated growth control are altered in HCC and that overall the TGF- $\beta$ pathway is altered in about $25 \%$ of HCCs.

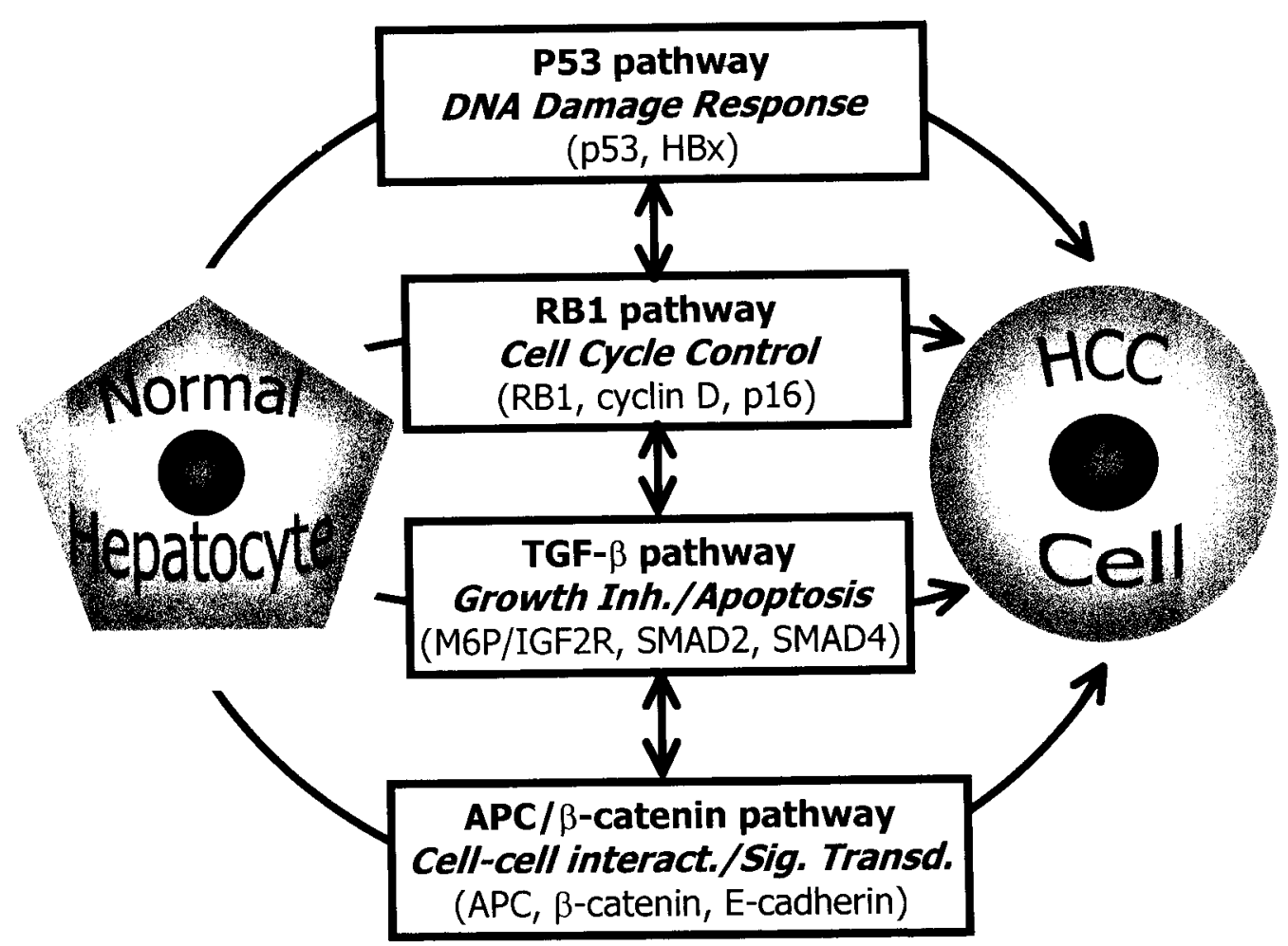

FIG. 1. Main regulatory pathways altered in human hepatocellular carcinomas. The most frequently mutated genes of each pathway are also shown. The vertical arrowed lines connecting four pathways indicate that these pathways are related to each other and they should not be considered as independent and separate pathways of hepatocellular carcinogenesis. 


\section{$\beta$-CATENIN, APC, AND E-CADHERIN GENES}

The $A P C$ gene was initially identified in the familial adenomatous polyposis coli syndrome. Germline and somatic mutations of $A P C$ have been detected in colorectal cancers. ${ }^{26}$ Some of these cancers display mutations in the $\beta$-catenin gene instead of the $A P C$ gene. ${ }^{27}$ $A P C$ and $\beta$-catenin proteins have physical and functional interactions. ${ }^{28} \beta$-Catenin also forms complexes with E-cadherin. ${ }^{29} A P C$ and E-cadherin may be involved in intercellular interactions. ${ }^{28,29}$ In contrast, $\beta$-catenin appears to play a role in transcriptional regulation in addition to its participation in cell-to-cell interactions. ${ }^{28}$ Somatic mutations of $\beta$-catenin were observed in $19-26 \%$ of $\mathrm{HCCs} .{ }^{30.31}$ These mutations that occur at the $\mathrm{N}$-terminal region of $\beta$-catenin lead to an accumulation of aberrant $\beta$-catenin proteins that stimulate the activity of a transcription factor. ${ }^{28,30,31}$ Somatic $A P C$ mutations may be rare in $\mathrm{HCC}$, but they appear to be quite frequent in hepatoblastomas. ${ }^{11,32-37}$ Finally, the E-cadherin gene was shown to display frequent $\mathrm{LOH}$ and de novo methylation in HCC (Table 1). Thus, it is possible that E-cadherin function is lost in some HCCs. Taken together, these observations indicate that the " $\beta$-catenin/APC pathway" is altered in more than $30 \%$ of HCCs.

\section{OTHER GENETIC ALTERATIONS}

As shown in Table 1, ras and myc oncogenes are not frequently mutated in human HCC. Loss of genomic imprinting and bi-allelic expression of the IGF2 gene was shown in hepatoblastomas and in some HCCs. ${ }^{38-43}$ Among other known genes, BRCA2, p21, and pISINK $4 B$ appear to be involved only rarely in these tumors. $M L H I$ and $M S H 2$, two genes involved in DNA mismatch repair, have not been studied for possible mutations in HCC (Table 1).

\section{CONCLUDING REMARKS}

Recent studies clearly indicate that many genes undergo somatic aberrations (point mutations, amplifications, loss of imprinting, de novo methylation, etc.) in HCC. The number of aberrant genes is high, but the frequency of individual gene mutations is low. However, these mutations are not random. They tend to cluster at genes involved in important growth regulatory pathways. Even though the picture is still imperfect, our present knowledge of the molecular genetics of HCC leads us to four main pathways that are altered in HCC: the $p 53$ pathway involved in DNA damage response, the
$R B 1$ pathway involved in cell cycle control, the TGF- $\beta$ pathway involved in growth inhibition and apoptosis, and the $\beta$-catenin/APC pathway involved in morphogenesis and signal transduction. As illustrated in Figure 1 , these pathways should not be considered as independent pathways. They are most probably related to each other and may even represent individually a distinct step of hepatocellular carcinogenesis. Unfortunately, our knowledge of the order of events for the initiation and stepwise progression of $\mathrm{HCC}$ is still incomplete.

Acknowledgment: Supported by grants from TUBITAK, TUBA (Turkey), and TWAS.

\section{ABBREVIATIONS}

\begin{tabular}{|c|c|}
\hline $\mathrm{HCC}$ & hepatocellular carcinoma \\
\hline HBV & hepatitis B virus \\
\hline $\mathrm{HCV}$ & hepatitis $\mathrm{C}$ virus \\
\hline M6P/IGF2R & $\begin{array}{l}\text { mannose-6-phosphate/insulin-like } \\
\text { growth factor II receptor }\end{array}$ \\
\hline$A P C$ & adenomatosis polyposis coli gene \\
\hline pl6INK4A & $\begin{array}{l}\text { gene coding for a } 16-\mathrm{kDa} \text { inhibitor of } \\
\text { cyclin-dependent kinase } 4 \text { enzyme }\end{array}$ \\
\hline$p I 5 I N K 4 B$ & $\begin{array}{l}\text { gene coding for a } 15-\mathrm{kDa} \text { inhibitor of } \\
\text { cyclin-dependent kinase } 4 \text { enzyme }\end{array}$ \\
\hline$B R C A 2$ & breast cancer susceptibility gene 2 \\
\hline $\mathrm{HBx}$ & $\mathrm{X}$ protein of hepatitis $\mathrm{B}$ virus \\
\hline $\mathrm{LOH}$ & loss of heterozygosity \\
\hline$R B I$ & retinoblastoma gene \\
\hline $\mathrm{pRb}$ & $\begin{array}{l}\text { protein encoded by the retinblastoma } \\
\text { gene }\end{array}$ \\
\hline IGF2 & insulin-like growth factor II \\
\hline pl9ARF & $\begin{array}{l}\text { protein encoded by an alternatively } \\
\text { spliced form of transcript from } \\
\text { pl6INK } 4 A \text { gene }\end{array}$ \\
\hline MDM2 & $\begin{array}{l}\text { human homolog of mouse double mu- } \\
\text { tant gene } 2\end{array}$ \\
\hline p21 & $\begin{array}{l}\text { 21-kDa cyclin-dependent kinase in- } \\
\text { hibitor protein also called CIP1 }\end{array}$ \\
\hline CDK4 & cyclin-dependent kinase 4 \\
\hline $\mathrm{E} 2 \mathrm{~F}$ & $\begin{array}{l}\text { a group of transcription factors regu- } \\
\text { lated by the retinoblastoma family of } \\
\text { pocket proteins }\end{array}$ \\
\hline TGF- $\beta$ & transforming growth factor $\beta$ \\
\hline$M L H 1$ & $\begin{array}{l}\text { gene encoding a protein involved in } \\
\text { DNA mismatch repair }\end{array}$ \\
\hline$M S H 2$ & $\begin{array}{l}\text { gene encoding for another protein in- } \\
\text { volved in DNA mismatch repair }\end{array}$ \\
\hline
\end{tabular}

\section{REFERENCES}

1. Ozturk M. Biology of hepatocellular carcinoma. In: AK Rustgi, ed. Gastrointestinal Cancers, Biology, Diagnosis, and Therapy. Philadelphia, PA: Lippincott-Raven, 1995, pp 511-525 
2. Buendia MA. Hepatitis B viruses and hepatocellular carcinoma. Adv Cancer Res 1992;59:167-226

3. Idilman R, De Maria N, Colantoni A, Van Thiel DH. Pathogenesis of hepatitis B and C-induced hepatocellular carcinoma. J Viral Hepat 1998:5:285-299

4. Puisieux A, Ozturk M. TP53 and hepatocellular carcinoma. Pathol Biol (Paris) 1997;45:864-870

5. Bressac B, Kew M, Wands J, Ozturk M. Selective G to T mutations of $p 53$ gene in hepatocellular carcinoma from southern Africa. Nature 1991;350:429-431

6. Hsu IC, Metcalf RA, Sun T, et al. Mutational hotspot in the $p 53$ gene in human hepatocellular carcinomas. Nature 1991; 350:427-428

7. Coursaget P, Depril N, Chabaud M, et al. High prevalence of mutations at codon 249 of the $p 53$ gene in hepatocellular carcinomas from Senegal. Br J Cancer 1993;67:1395-1397

8. Ozturk M, Puisieux A, Kew M, et al. p53 mutation in hepatocellular carcinoma after aflatoxin exposure. Lancet 1991;338: 1356-1359

9. Unsal H, Yakicier C, Marcais C, et al. Genetic heterogeneity of hepatocellular carcinoma. Proc Natl Acad Sci USA 1994; 91:822-826

10. Li D, Cao Y, He L, Wang NJ, Gu JR. Aberrations of $p 53$ gene in human hepatocellular carcinoma from China. Carcinogenesis 1993;14:169-173

11. Fujimoto Y, Hampton LL, Wirth PJ, et al. Aiterations of tumor suppressor genes and allelic losses in human hepatocellular carcinomas in China. Cancer Res 1994;54:281-285

12. Greenblatt MS, Feitelson MA, Zhu M, et al. Integrity of $p 53$ in hepatitis $\mathrm{B} x$ antigen-positive and -negative hepatocellular carcinomas. Cancer Res 1997;57:426-432

13. Wang XW, Forrester $\mathrm{K}$, Yeh $\mathrm{H}$, et al. Hepatitis B virus $\mathrm{X}$ protein inhibits $p 53$ sequence-specific DNA binding, transcriptional activity, and association with transcription factor ERCC3. Proc Natl Acad Sci USA 1994;91:2230-2234

14. Ueda $\mathrm{H}$, Ullrich SJ, Gangemi JD, et al. Functional inactivation but not structural mutation of $p 53$ causes liver cancer. Nat Genet 1995;9:41-47

15. Elmore LW, Hancock AR, Chang SF, et al. Hepatitis B virus $X$ protein and $p 53$ tumor suppressor interactions in the modulation of apoptosis. Proc Natl Acad Sci USA 1997;94:14707-14712

16. Greenblatt MS, Bennett WP, Hollstein M, Harris CC. Mutations in the $p 53$ tumor suppressor gene: clues to cancer etiology and molecular pathogenesis. Cancer Res 1994;54:4855-4878

17. Prives C. Signalling to $p 53$ : breaking the MDM2-p53 circuit. Cell 1998;95:5-8

18. Reed SI. Control of the Gl/S transition. Cancer Surv 1997; 29:7-23

19. Johnson DG, Schneider-Broussard R. Role of E2F in cell cycle control and cancer. Front Biosci 1998;3:447-448

20. Razin A. CpG methylation, chromatin structure and gene silencing-a three-way connection. EMBO J 1998;17:4905-4908

21. De Souza AT, Hankins GR, Washington MK, Orton TC, Jirtle RL. $M 6 P / I G F 2 R$ gene is mutated in human hepatocellular carcinomas with loss of heterozygosity. Nat Genet 1995; 11:447-449

22. Thorgeirsson SS, Teramoto T, Factor VM. Dysregulation of apoptosis in hepatocellular carcinoma. Semin Liver Dis 1998; $18: 115-122$

23. Derynck R, Zhang Y, Feng XH. Smads: Transcriptional activators of TGF-beta responses. Cell 1998;95:737-740

24. Kawate S, Takenoshita S, Ohwada S, et al. Mutation analysis of transforming growth factor type II receptor, smad2, and smad4 in hepatocellular carcinoma. Int J Oncol 1999;14:127-131

25. Yakicier MC, Irmak MB, Romano A, Kew M, Ozturk M. Smad2 and Smad4 gene mutations in hepatocellular carcinoma. Oncogene (in press).
26. Kinzler KW, Vogelstein B. Lessons from hereditary colorectal cancer. Cell 1996;87:159-170

27. Morin PJ, Sparks AB, Korinek V, et al. Activation of betacatenin-Tcf signaling in colon cancer by mutations in betacatenin or APC. Science 1997;275: 1787-1790

28. Peifer M. Beta-catenin as oncogene: the smoking gun. Science 1997;275:1752-1753

29. Hirohashi S. Inactivation of the E-cadherin-mediated cell adhesion system in human cancers. Am J Pathol 1998;153:333-339

30. de La Coste A, Romagnolo B, Billuart P, et al. Somatic mutations of the beta-catenin gene are frequent in mouse and human hepatocellular carcinomas. Proc Natl Acad Sci USA 1998;95: 8847-8851

31. Miyoshi $Y$, Iwao K, Nagasawa $Y$, et al. Activation of the betacatenin gene in primary hepatocellular carcinomas by somatic alterations involving exon 3 . Cancer Res 1998;58:2524-2547

32. Horii A, Nakatsuru S, Miyoshi Y, et al. Frequent somatic mutations of the APC gene in human pancreatic cancer. Cancer Res 1992;52:6696-6698

33. Kurahashi $\mathrm{H}$, Takami $\mathrm{K}$, Oue $\mathrm{T}$, et al. Biallelic inactivation of the APC gene in hepatoblastoma. Cancer Res 1995;55:5007-5011

34. Giardiello FM, Petersen GM, Brensinger JD, et al. Hepatoblastoma and APC gene mutation in familial adenomatous polyposis. Gut 1996;39:867-869

35. Gruner BA, DeNapoli TS, Andrews W, Tomlinson G, Bowman L, Weitman SD. Hepatocellular carcinoma in children associated with Gardner syndrome or familial adenomatous polyposis. J Pediatr Hematol Oncol 1998;20:274-278

36. Piao Z, Choi Y, Park C, Lee WJ, Park JH, Kim H. Deletion of the $M 6 P / I G F 2 r$ gene in primary hepatocellular carcinoma. Cancer Lett 1997;120:39-43

37. Oda H, Imai Y, Nakatsuru Y, Hata J, Ishikawa T. Somatic mutations of the $A P C$ gene in sporadic hepatoblastomas. Cancer Res 1996;56:3320-3323

38. Rainier S, Dobry CJ, Feinberg AP. Loss of imprinting in hepatoblastoma. Cancer Res 1995;55:1836-1838

39. Li X, Adam G, Cui H, Sandstedt B, Ohlsson R, Ekstrom TJ. Expression, promoter usage and parental imprinting status of insulin-like growth factor II (IGF2) in human hepatoblastoma: uncoupling of IGF2 and H19 imprinting. Oncogene 1995;11:221229

40. Takeda S, Kondo M, Kumada T, et al. Allelic-expression imbalance of the insulin-like growth factor 2 gene in hepatocellular carcinoma and underlying disease. Oncogene 1996;12:1589- 1592

41. Kim KS, Lee YI. Biallelic expression of the $H 19$ and $I G F 2$ genes in hepatocellular carcinoma. Cancer Lett 1997;119:143-148

42. Li X, Kogner P, Sandstedt B, Haas OA, Ekstrom TJ. Promoter-specific methylation and expression alterations of igf 2 and $\mathrm{h} 19$ are involved in human hepatoblastoma. Int J Cancer 1998;75: 176-180

43. Li X, Nong Z, Ekstrom C, et al. Disrupted IGF2 promoter control by silencing of promoter $\mathrm{P} 1$ in human hepatocellular carcinoma. Cancer Res 1997;57:2048-2054

44. Yamada T, De Souza AT, Finkelstein S, Jirtle RL. Loss of the gene encoding mannose 6-phosphate/insulin-like growth factor II receptor is an early event in liver carcinogenesis. Proc Natl Acad Sci USA 1997;94:10351-10355

45. Murakami Y, Hayashi K, Hirohashi S, Sekiya T. Aberrations of the tumor suppressor $p 53$ and retinoblastoma genes in human hepatocellular carcinomas. Cancer Res 1991;51:5520-5525

46. Nakamura T, Iwamura Y, Kaneko M, et al. Deletions and rearrangements of the retinoblastoma gene in hepatocellular carcinoma, insulinoma and some neurogenic tumors as found in a study of 121 tumors. Jpn J Clin Oncol 1991;21:325-329

47. Nishida N, Fukuda Y, Kokuryu H, et al. Accumulation of allelic loss on arms of chromosomes $13 \mathrm{q}, 16 \mathrm{q}$ and $17 \mathrm{p}$ in the advanced stages of human hepatocellular carcinoma. Int $\mathrm{J}$ Cancer 1992;51:862-868 
48. Zhang X, Xu HJ, Murakami Y, et al. Deletions of chromosome $13 \mathrm{q}$, mutations in retinoblastoma 1 , and retinoblastoma protein state in human hepatocellular carcinoma. Cancer Res 1994;54:4177-4182

49. Ashida K, Kishimoto Y, Nakamoto K, et al. Loss of heterozygosity of the retinoblastoma gene in liver cirrhosis accompanying hepatocellular carcinoma. J Cancer Res Clin Oncol 1997;123: 489-495

50. Iolascon A, Giordani L, Moretti A, Basso G, Borriello A, Della Ragione F. Analysis of CDKN2A, CDKN2B, CDKN2C, and cyclin Ds gene status in hepatoblastoma. Hepatology 1998; 27:989-995

51. Lin $\mathrm{YW}$, Chen $\mathrm{CH}$, Huang GT, et al. Infrequent mutations and no methylation of CDKN2A (P16/MTS1) and CDKN2B (p15/MTS2) in hepatocellular carcinoma in Taiwan. Eur J Cancer 1998;34:1789-1795

52. Kita R, Nishida N, Fukuda Y, et al. Infrequent alterations of the pl6INK4A gene in liver cancer. Int J Cancer 1996;67:176-180

53. Chaubert P, Gayer R, Zimmermann A, et al. Germ-line muta tions of the pl6INK4(MTS1) gene occur in a subset of patients with hepatocellular carcinoma. Hepatology 1997; 25 1376-1381

54. Kim JR, Kim SY, Kim MJ, Kim JH. Alterations of CDKN2 (MTSI/p16INK4A) gene in paraffin-embedded tumor tissues of human stomach, lung, cervix and liver cancers. Exp Mol Med 1998;30: 109-114

55. Furutani M, Arii S, Tanaka H, et al. Decreased expression and rare somatic mutation of the CIPI/WAF/ gene in human hepatocellular carcinoma. Cancer Lett 1997;111:191-197

56. Zhang YJ, Jiang W, Chen CJ, et al. Amplification and overexpression of cyclin D1 in human hepatocellular carcinoma. Biochem Biophys Res Commun 1993;196:1010-1016

57. Nishida N, Fukuda Y, Komeda T, et al. Amplification and overexpression of the cyclin D1 gene in aggressive human hepatocellular carcinoma. Cancer Res 1994;54:3107-3110

58. Wang J, Chenivesse X, Henglein B, Brechot C. Hepatitis B virus integration in a cyclin $\mathrm{A}$ gene in a hepatocellular carcinoma. Nature 1990;343:555-557

59. Chao Y, Shih YL, Chiu JH, et al. Overexpression of cyclin A but not Skp 2 correlates with the tumor relapse of human hepatocellular carcinoma. Cancer Res 1998;58:985-890

60. Slagle BL, Zhou YZ, Birchmeier W, Scorsone KA. Deletion of the $\mathrm{E}$-cadherin gene in hepatitis B virus-positive Chinese hepatocellular carcinomas. Hepatology 1993;18:757-762

61. Kanai Y, Ushijima S, Hui AM, et al. The E-cadherin gene is silenced by $\mathrm{CpG}$ methylation in human hepatocellular carcinomas. Int J Cancer 1997;71:355-359

62. Katagiri T, Nakamura Y, Miki Y. Mutations in the BRCA2 gene in hepatocellular carcinomas. Cancer Res 1996;56:4575-4577

63. Macdonald GA, Greenson JK, Saito K, Cherian SP, Appelman HD, Boland CR. Microsatellite instability and loss of heterozygosity at DNA mismatch repair gene loci occurs during hepatic carcinogenesis. Hepatology 1998;28:90-97

64. De Benedetti VM, Welsh JA, Trivers GE, et al. p53 is not mutated in hepatocellular carcinomas from Alaska Natives. Cancer Epidemiol Biomarkers Prev 1995;4:79-82

65. Shieh YS, Nguyen C, Vocal MV, Chu HW. Tumor-suppressor p53 gene in hepatitis $\mathrm{C}$ and $\mathrm{B}$ virus-associated human hepatocellular carcinoma. Int J Cancer 1993;54:558-562

66. Goldblum JR, Bartos RE, Carr KA, Frank TS. Hepatitis B and alterations of the $p 53$ tumor suppressor gene in hepatocellular carcinoma. Am J Surg Pathol 1993; 17:1244-1251

67. Kazachkov Y, Khaoustov V, Yoffe B, Solomon H, Kiintmalm GB, Tabor E. p53 abnormalities in hepatocellular carcinoma from United States patients: Analysis of all 11 exons. Carcinogenesis 1996;17:2207-2212

68. De Benedetti VM, Welsh JA, Yu MC, Bennett WP. p53 mutations in hepatocellular carcinoma related to oral contraceptive use. Carcinogenesis 1996;17:145-159
69. Honda $\mathrm{K}$, Sbisa E, Tullo A, et al. p53 mutation is a poor prognostic indicator for survival in patients with hepatocellular carcinoma undergoing surgical tumour ablation. Br J Cancer 1998; 77:776-782

70. Soini Y, Chia SC, Bennett WP, et al. An aflatoxin-associated mutational hotspot at codon 249 in the p53 tumor suppressor gene occurs in hepatocellular carcinomas from Mexico. Carcinogenesis 1996;17:1007-1012

71. Kennedy SM, Macgeogh C, Jaffe R, Spurr NK. Overexpression of the oncoprotein $p 53$ in primary hepatic tumors of childhood does not correlate with gene mutations. Hum Pathol 1994;25: 438-442

72. Kubicka S, Trautwein C, Schrem H, Tillmann H, Manns M. Low incidence of $p 53$ mutations in European hepatocellular carcinomas with heterogeneous mutation as a rare event. $\mathbf{J}$ Hepatol $1995 ; 23: 412-419$

73. Kress S, Jahn UR, Buchmann A, Bannasch P, Schwarz M. p53 mutations in human hepatocellular carcinomas from Germany. Cancer Res 1992;52:3220-3223

74. Pontisso P, Belluco C, Bertorelle R, et al. Hepatitis C virus infection associated with human hepatocellular carcinoma: Lack of correlation with p53 abnormalities in Caucasian patients. Cancer 1998;83:1489-1494

75. Challen C, Lunec J, Warren W, Collier J, Bassendine MF. Analysis of the $p 53$ tumor suppressor gene in hepatocellular carcinomas from Britain. Hepatology 1992;16:1362-1366

76. Yumoto $\mathrm{Y}$, Hanafusa $\mathrm{T}$, Hada $\mathrm{H}$, et al. Loss of heterozygosity and analysis of mutation of $p 53$ in hepatocellular carcinoma. J Gastroenterol Hepatol 1995; 10:179-185

77. Debuire B, Paterlini P, Pontisso P, Basso G, May E. Analysis of the $p 53$ gene in European hepatocellular carcinomas and hepatoblastomas. Oncogene 1993;8:2303-2306

78. Scorsone KA, Zhou YZ, Butel JS, Slagle BL. p53 mutations cluster at codon 249 in hepatitis B virus-positive hepatocellular carcinomas from China. Cancer Res 1992;52:1635-1638

79. Yang M, Zhou H, Kong RY, et al. Mutations at codon 249 of p53 gene in human hepatocellular carcinomas from Tongan, China. Mutat Res 1997;381:25-29

80. Ng IO, Srivastava G, Chung LP, Tsang SW, Ng MM. Overexpression and point mutations of $p 53$ tumor suppressor gene in hepatocellular carcinomas in Hong Kong Chinese people. Cancer 1994;74:30-37

81. Lunn RM, Zhang YJ, Wang LY, et al. $p 53$ mutations, chronic hepatitis $B$ virus infection, and aflatoxin exposure in hepatocellular carcinoma in Taiwan. Cancer Res 1997;57:3471-3477

82. Diamantis ID, McGandy C, Chen TJ, Liaw YF, Gudat F, Bianchi L. A new mutational hot-spot in the $p 53$ gene in human hepatocellular carcinoma. J Hepatol 1994;20:553-556

83. Sheu JC, Huang GT, Lee PH, et al. Mutation of $p 53$ gene in hepatocellular carcinoma in Taiwan. Cancer Res 1992;52:6098-6100

84. Shi CY, Phang TW, Lin Y, et al. Codon 249 mutation of the p.53 gene is a rare event in hepatocellular carcinomas from ethnic Chinese in Singapore. Br J Cancer 1995; 72:146-149

85. Hollstein MC, Wild CP, Bleicher F, et al. p53 mutations and aflatoxin $\mathrm{B} 1$ exposure in hepatocellular carcinoma patients from Thailand. Int J Cancer 1993;53:51-55

86. Hayashi H, Sugio K, Matsumata T, et al. Tanaka S, Sugimachi K The mutation of codon 249 in the $p 53$ gene is not specific in Japanese hepatocellular carcinoma. Liver 1993;13:279-281

87. Nose H, Imazeki F, Ohto M, Omata M. p53 gene mutations and $17 \mathrm{p}$ allelic deletions in hepatocellular carcinoma from Japan. Cancer 1993;72:355-360

88. Tanaka S, Toh Y, Adachi E, Matsumata T, Mori R, Sugimachi K. Tumor progression in hepatocellular carcinoma may be mediated by $p 53$ mutation. Cancer Res 1993;53:2884-2887

89. Vesey DA, Hayward NK, Cooksley WG. p53 gene in hepatocellular carcinomas from Australia. Cancer Detect Prev 1994;18:123-130 
90. Tsuda H, Hirohashi S, Shimosato Y, Ino Y, Yoshida T, Terada M. Low incidence of point mutation of $\mathrm{c}-\mathrm{Ki}$-ras and $\mathrm{N}$-ras oncogenes in human hepatocellular carcinoma. Jpn J Cancer Res 1989;80:196-199

91. Tada M, Omata M, Ohto M. Analysis of ras gene mutations in human hepatic malignant tumors by polymerase chain reaction and direct sequencing. Cancer Res 1990;50:1121-1124

92. Stork P, Loda M, Bosari S, Wiley B, Poppenhusen K, Wolfe H. Detection of K-ras mutations in pancreatic and hepatic neoplasms by non-isotopic mismatched polymerase chain reaction. Oncogene 1991;6:857-862

93. Challen C, Guo K, Collier JD, Cavanagh D, Bassendine MF. Infrequent point mutations in codons 12 and 61 of ras oncogenes in human hepatocellular carcinomas. J Hepatol 1992;14:342346

94. Lin SY, Chen PH, Wang CK, et al. Mutation analysis of K-ras oncogenes in gastroenterologic cancers by the amplified created restriction sites method. Am J Clin Pathol 1993;100:686-689

95. Leon M, Kew MC. Analysis of ras gene mutations in hepatocellular carcinoma in southern African blacks. Anticancer Res $1995 ; 15: 859-861$

96. Zhang XK, Huang DP, Qiu DK, Chiu JF. The expression of $\mathrm{c}-m y c$ and c-N-ras in human cirrhotic livers, hepatocellular carcinomas and liver tissue surrounding the tumors. Oncogene 1990;5:909-914
97. Ogata N, Kamimura T, Asakura H. Point mutation, allelic loss and increased methylation of c-Ha-ras gene in human hepatocellular carcinoma. Hepatology 1991;13:31-37

98. Bjersing L, Andersson C, Lithner F. Hepatocellular carcinoma in patients from northern Sweden with acute intermittent porphyria: morphology and mutations. Cancer Epidemiol Biomarkers Prev 1996;5:393-397

99. Tsuda H, Shimosato Y, Upton MP, et al. Retrospective study on amplification of N-myc and c-myc genes in pediatric solid tumors and its association with prognosis and tumor differentiation. Lab Invest 1988;59:321-327

100. Abou-Elella A, Gramlich T, Fritsch C, Gansler T. c-myc amplification in hepatocellular carcinoma predicts unfavorable prognosis. Mod Pathol 1996;9:95-98

101. Mares J, Polanska V, Gorgens H, et al. Oncogene amplification and expression in pediatric solid tumors. Neoplasma 1998; 45:1 23-127

102. Nishida N, Fukuda Y, Kokuryu H, et al. Role and mutational heterogeneity of the $p 53$ gene in hepatocellular carcinoma. Cancer Res 1993;53:368-372

103. Oda T, Tsuda H, Scarpa A, Sakamoto M, Hirohashi S. p53 gene mutation spectrum in hepatocellular carcinoma. Cancer Res 1992;52:6358-6364

104. Kang YK, Kim CJ, Kim WH, Kim HO, Kang GH, Kim YI. p53 mutation and overexpression in hepatocellular carcinoma and dysplastic nodules in the liver. Virchows Arch 1998;432:27-32 